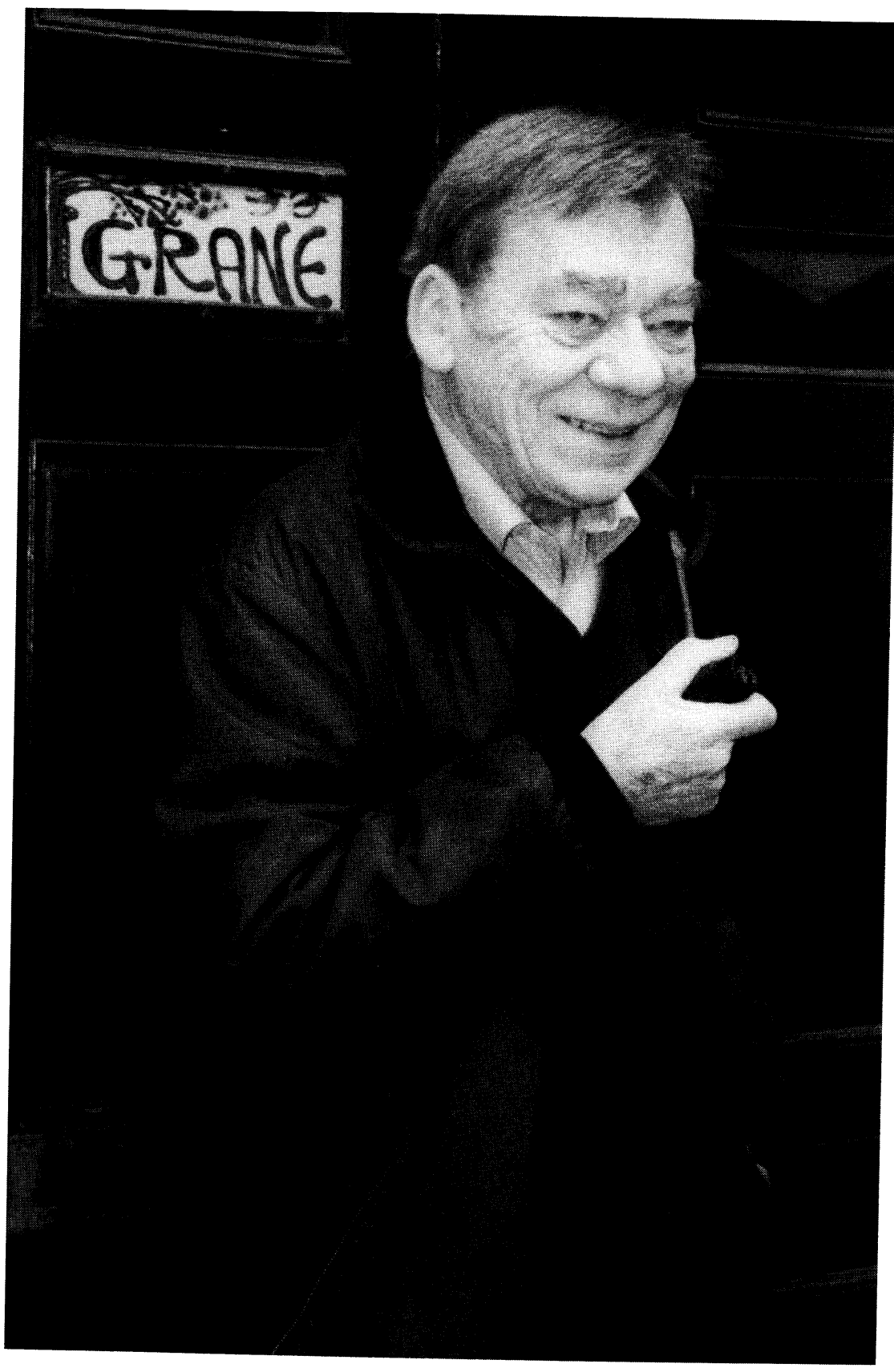




\section{Leif Grane in memoriam}

$(1928-2000)$

Det var som Lutherforsker og reformationshistoriker, professor, dr. theol. Leif Grane var mest kendt. Centralt står disputatsen »Contra Gabrielem « (1962) og ikke mindst de senere Luthermonografier »Modus loquendi theologicus" (1975) og "Martinus Noster" (1994), alle tre værker, der er karakteristiske ved deres eminente læsning af Lutherteksterne og ikke mindre bemærkelsesværdige ved deres metodiske enkelhed, hvor Luther ikke læses systematisk med henblik på at nå frem til den »rene « lutherske theologi, men ud fra Luthers eget pointerede anliggende og følgende dettes udfoldelse i den fremadskridende tekst. Lutherteksten som et levende menneskes tankebevægelse - ikke et arsenal til konstruktion af den endegyldige lutherske theologi!

Ud af det intense arbejde med Luthers tekster voksede en stribe mere folkeligt anlagte bøger på dansk om reformationen og dens anliggende. Allerede i 1958 udsendte han »Confessio Augustana", en oversættelse af bekendelsen samt en kortfattet indføring i den reformatoriske theologi. På samme linie ligger oversættelserne af »Den danske folkekirkes bekendelsesskrifter « og »Den store Katekismus«, begge fra 1976. Det blev til to store bøger om Luther, af hvilke den senere "Evangeliet for folket. Drøm og virkelighed i Martin Luthers liv« (1983), så vidt jeg kan vurdere, giver læseren et bedre indtryk af Granes omgang med Luthers tekster end den første »Protest og konsekvens. Faser i Martin Luthers tænkning indtil 1525« (1968).

Grane var en umådelig lærd mand og vidt belæst. Hans forfatterskab rummer bøger og afhandlinger, der omfatter hele kirkens historie. Et indtryk af bredden $\mathrm{i}$ hans kirkehistoriske arbejde făr man for eksempel i samleværket »Kirken i historien « (1988), der samtidig rummer den anden, ikke mindre vigtige pol i Granes forfatterskab: Den standende theologiske strid!

Lige så lidenskabelig brysk han kunne være i den offentlige debat, lige så imødekommende og mild - jeg kan ikke finde bedre ord - kunne han være som underviser og vejleder for de studerende på Københavns Universitet. Jeg husker en lille privat studiekreds omkring Grane, hvor vi var en gruppe, der læste Augustins ॥Enchiridion« - på latin, hvad ellers? Det var forunderlige aftener, der ofte trak længe ud, og hvor næsten ethvert theologisk tolkningsforsøg fik lov at blive fremført, men ikke uden at blive mødt med kravet om at forklare sig, for »theologien 
har vi kun på forståelsens vilkår«. Man blev ikke del af et meningsfællesskab eller i det hele taget »oplært « til bestemte synspunkter, men lærte det langt vigtigere, at respektere det møjsommelige arbejde med teksterne og først og fremmest theologiens sag.

Hermed står vi ved noget afgørende, der kendetegner såvel Granes forskningsmæssige indsats, som hans deltagelse i den aktuelle debat: Respekten for det saglige theologiske arbejde! Det er slående, når man læser/genlæser hans indlæg i den standende theologiske samtale, at de i meget vidt omfang drejer omkring den akse, der udgøres af det grundlæggende spørgsmål: Hvad er theologi overhovedet? Det var et spørgsmål, der ikke klaredes én gang for alle, hvorefter man kunne gå over til det næste - egentlige - spørgsmål på dagsordenen, men krævede stadig besindelse. Da han i 1981 skulle tale ved Det theologiske Fakultets årsfest $\mathrm{i}$ Århus, holdt han et foredrag med titelen $»$ Karl Barth og nutidens theologi« (»Kristendommen i historien. Udvalgte artikler 1950-1996«). Det var en bidende indsigelse mod forsøget på at løbe fra det, der er theologiens blivende opgave, som ikke kan være en anden sandhed ॥ved siden af den sandhed, som det er prædikenens opgave at gøre gældende. "Genstanden for det theologiske arbejde er det ikke op til theologien selv at finde, men den er givet den på forhånd i det ord, som er kirkens eneste eksistensberettigelse - og altså theologiens! En theologi, der selv vælger sin genstand og ud af sine overvejelser skaber sin egen $» k r i s t e n-$ dom «, er ikke theologi, men fantasteri.

For de markeret sikre fortalere for »det lutherske« kom Grane nok ofte til at stå som sivet, der svajer for vinden, når han afviste at gøre fælles front med dem - netop han, der dog var Luther-kenderen frem for nogen! Men dels var han, som nævnt, ingen stor beundrer af »meningsfællesskaber « - heller ikke uden for de mere snævre økumeniske konferencesammenhænge - dels så han i den mere eller mindre direkte overtagelse af Luthers positioner et forsøg på at springe den selvstændige theologiske tilegnelse over. I den lille fine bog "Historien om Martin Luther « (1983), som blev udsendt til alle menighedsrådsmedlemmer i Danmark, udtrykte han det således:

Uden at ville andet end at prædike Kristus rystede han (Luther) pavedømmet og satte verden på den anden ende. I den enhed af person og sag, som gjorde det muligt, ligger hans arv til eftertiden. Har man forstået det, behøver man hverken at forgude ham eller at gøre ham til et uforanderligt mønster for al teologi. Det er langt vig- 
tigere at lytte til ham og selv tage hans tilskyndelser op på egne betingelser. Det er ikke gjort med at henvise til ham alene. Først når man ser sig selv henvist til sammenhængen mellem evangeliet og det sted, man selv befinder sig på, nytter det noget.

Jeg tror, man skal læse Granes forfatterskab ualmindeligt overfladisk for ikke at bemærke den danske theologiske traditions nerve, som er til stede deri. Det gælder ikke alene indlæggene i den aktuelle debat, men også , så vidt jeg kan skønne, hans arbejde med Luthers tekster. At der hermed skulle være sagt noget relativerende om hans arbejde med reformatoren gælder kun, hvis man mener, at theologi er en art religionsvidenskab med sit eget udgangspunkt og sit eget formål. Det gælder derimod ikke, hvis theologien møder os som den traditionens strøm, vi ikke kan tænkes uden og derfor er forpligtiget på. At Grundtvig indtager en betydelig plads i denne tradition, som den møder læseren i Granes bøger og afhandlinger, kommer ikke mindst frem i den gentagne betoning af den historiske sammenhæng som ethvert sobert theologisk arbejdes uomgængelige vilkår.

I et foredrag Grane holdt på et internationalt symposium i Heidelberg i 1982 gjorde han Grundtvigs forståelse af Luther direkte gældende i international sammenhæng (Foredraget $» L u t h e r$ i Danmark « er optaget i bogen $»$ Den uberegnelige Luther. Essays om en arv og dens forvaltning." (1992) ss. 133-145). Det er et meget vægtigt foredrag, i vidt omfang refererende til den tale til »Luthers minde«, Grundtvig holdt i alle sine år ved Vartov. Foredraget er i denne sammenhæng ikke mindre vigtigt, fordi det samler overvejelser om forholdet mellem Grundtvig og Luther, der findes spredt rundt omkring i Granes forfatterskab. Foredragets titel er altså »Luther i Danmark «, men det er sigende for Granes vurdering af Grundtvigs Lutherforståelse, at mens al øvrig Lutherlæsning i Danmark tilmåles omkring 4 sider, indrømmes Grundtvigs læsning af Luther det dobbelte.

I foredraget $\mathrm{g} ø \mathrm{r}$ Grane indledningsvis opmærksom på, at netop i Danmark »har en mand af stort format beskæftiget sig med Luther på en original måde, hvortil man næppe finder mage. Jeg tænker ikke på Søren Kierkegaard, men på Grundtvig." (s. 133).

Grundlæggende gælder, at i forhold til sin samtids omgang med reformatoren var Grundtvigs læsning af Luther ikke primært opbyggelig, men theologisk bestemt, og derfor på enestående vis opmærksom på Luthers anliggende. 
Med den »kirkelige anskuelse« kom Grundtvig imidlertid i konflikt med det protestantiske skriftprincip, som i århundrederne efter Luther var blevet fikseret dogmatisk som selve kernen i reformationen, og som Grundtvig selv havde hyldet. Ikke mindst i sin omfangsrige $» k r ø n i k e-$ litteratur « retter Grundtvig mange drøje hug mod den lutherdom, der, så vidt han kunne se, i sin rettroenhed havde svigtet Luthers anliggende. »Den tid«, siger Grundtvig et sted i »Luthers Minde«, »da man var nær ved at glemme baade Kristus og hans Aand over Morten Luther, afløstes af en anden Tid, da man var nær ved at glemme baade Luther og Kristus over sin egen, for det meste meget fattige og altid ukristelige, Fornuft og Forstand.» Det er ortodoksien og rationalismen, Grundtvig her peger på som de hovedtendenser, der har skjult reformationens ærinde - også for ham selv, om end i omvendt rækkefølge.

Men før eller siden måtte han i sit kritiske opgør med den lutherske tradition spørge, om det kun var et tilfælde, at den var endt i det »eksegetiske pavedømme», eller om der i Luthers egen theologiske ansats var historisk betingede forhold, der om ikke ligefrem nødvendigvis måtte føre dertil, så i hvert fald ikke kunne siges at være uden ansvar derfor. »Fra virkningerne af skriftprincippet hos teologerne i det begyndende 19. Århundrede følger han (Grundtvig) dem baglæns tilbage til oprindelsen hos Luther. Hos reformatoren havde det endnu god mening at beråbe sig på Bibelen, men nu har Bibelkritikken gjort det umuligt. Efter at mange har udskiftet den lutherske skriftfortolkning med fornuften, kan troskaben mod Luthers tro kun fastholdes i forbindelse med en afvisning af den lutherske metode i teologien. ... Fejlen er ganske vist først kommet til fuld udfoldelse i den rationalistiske teologi, men i kim er den allerede til stede i Luthers sola scriptura (Skriften alene).« (s. 141).

Grane gør opmærksom på, at Grundtvigs kritiske syn på den lutherske kirkes historie i sig selv ikke er enestående, men, som han meget afdæmpet udtrykker det, »den nærmere begrundelse hos Grundtvig fortjener dog opmærksomhed." (s. 142). Derpå sammenfattes Grundtvigs mellemværende med Luther og lutherdommen i fire punkter, der, som der gøres opmærksom på, overlapper hinanden, men den grundlæggende kritik med henblik på skriftprincippet er lutherdommens manglende sondring mellem »»Kirke og Skole«, eller, om man vil, mellem tro og teologi.« (s. 142). Den manglende sondring mellem tro og theologi betød, at theologien fik tilkendt en stilling i kirken, som ikke med rette var dens. "Luther kan altså ikke fries fra ansvaret for at have givet »skolen«, 
dvs. den teologiske lærdom, en dominans i kirken, som aldeles ikke tilkommer den. ... Det eneste lys i dette mørke af teologisk vilkårlighed ser Grundtvig i, at Den lille Katekismus og salmerne ved gudstjenesten har fastholdt kirkens trosvidnesbyrd gennem århundrederne. « (s. 143).

Det er ikke noget tilfælde, at netop i en sammenfatning af Grundtvigs syn udtrykker Grane også, forekommer det mig, et centralt moment i sit eget virke såvel inden for som uden for universitetets mure: »Et levende vidnesbyrd er Skriften ikke, og uden et sådant vidnesbyrd ville menigheden være reduceret til et læseselskab, hvori kun de lærde havde noget at skulle have sagt. Hvad de siger, kan, selv hvis det blev sagt af en Luther, aldrig erstatte menighedens levende vidnesbyrd. De lærdes skriftudlægning skal udøves i åndelig frihed - og forbliver just derved diskutabel. Grundtvig kan ikke forestille sig noget menneske, der ville være parat til at dø på sin egen skriftudlægning. Over for døden kan ingen bestå med mindre end troen på Kristi nærværende, levende ord. Men det, der ikke forslår i døden, vil heller ikke være nok i livet. At forlade sig på den beskrivelse af troen, som foreligger i Det nye Testamente, ville sige at forlade sig på skyggen af sin præsts tro. Den kristne tro er netop ikke diskutabel, dvs. den kan ikke leve af teologien, men kun af Guds levende ord, som det er overleveret i menigheden siden apostlenes dage.« (ss. 143-144). Hvad er for eksempel dette, at »De lærdes skriftudlægning skal udøves i åndelig frihed - og forbliver just derved diskutabel«, andet end »teologien har vi kun på forståelsens vilkår«?

Det er i sig selv en kvalitet ved Granes læsning af Grundtvig, at den går til Grundtvigs tekster med det »diskutable« som målestok. Læst $\mathrm{i}$ "skolen« levnes der ingen mulighed for med henvisning til "hjertet" eller »det poetiske« eller hvad det nu måtte være, at unddrage dem den menneskelige forståelses krav om »klare grunde«. Netop ved i sit arbejde at fastholde forståeligheden som ubetinget krav, kan theologen give sit ydmyge bidrag til, at kristendommen ikke forvandles til en sag for de »lærde blot«, men for ethvert menneske:

Der findes også i disse tider, hvor vi har vænnet os til kravet om "forskning for folket» stadigvæk fag, som har deres egenværdi, skønt de kun indirekte og måske noget fortyndet kan udbredes i videre kredse. Teologien hører ikke til disse fag. Den mister sin mening, hvis den ikke kan bruges i menigheden. Dette betyder selvfølgelig ikke, at man skal falde for billige brugbarhedskriterier, men det betyder, at teologien principielt er rettet hen mod menig- 
heden, omend mange af dens resultater i den oprindelige form kun er direkte tilgængelige for fagfolk.

(Fra foredraget $»$ Reformation og kirke idag «. I op. cit. s. 151).

De her omtalte synspunkter tog Grane op påny og udbyggede dem i afhandlingen »Grundtvigs forhold til Luther og den lutherske tradition«, Grundtvig Studier 1998, s. 21-41).

Med Leif Granes død har dansk theologi og den internationale Luther-forskning, men før noget andet den danske menighed mistet en vægtig stemme.

Henrik True 